\title{
The carnivoran-like insectivore Butselia biveri Quinet \& Misonne, 1965 (Mammalia, Plesiosoricidae) from the lowermost Oligocene of Europe
}

\author{
Richard SMITH* \& Thierry SMITH
}

Département de Paléontologie, Institut Royal des Sciences Naturelles de Belgique, rue Vautier 29, B-1000 Bruxelles, Belgium; richardsmithpal@hotmail.com; thierry.smith@sciencesnaturelles.be

* Corresponding author

Smith, R. \& Smith, T. 2012. The carnivoran-like insectivore Butselia biveri Quinet \& Misonne, 1965 (Mammalia, Plesiosoricidae) from the lowermost Oligocene of Europe. [El insectívoro carnivoroide Butselia biveri Quinet \& Misonne, 1965 (Mammalia, Plesiosoricidae) del inicio del Oligoceno inferior en Europa]. Spanish Journal of Palaeontology, 27 (2), $105-116$.

\section{ABSTRACT}

Plesiosoricidae is a small extinct family of soricomorphan insectivores distributed from the Early Eocene to the Late Miocene on the three continents of the Northern Hemisphere. One of two known plesiosoricid subfamilies is represented by the particular Eurasian subfamily Butseliinae. Here we describe new dental and postcranial elements of Butselia biveri, the type-species of the genus Butselia from the lowermost Oligocene of Belgium. The specialized anterior dentition shows a strong caniniform i2 while the upper and lower molars show a remarkable convergent evolution with early carnivorans, especially the small Early Eocene miacids. Tarsal bones of Butselia biveri are also identified and described, suggesting a closely relationship with Nyctitheriidae but also indicating some convergent features with small scansorial carnivorans.

Keywords: Soricomorpha, Plesiosoricidae, Butselia, MP21, Belgium.

\section{RESUMEN}

Plesiosoricidae es una pequeña familia extinta de insectívoros soricomorfos distribuidos desde el Eoceno temprano al Mioceno tardío en los tres continentes del Hemisferio Norte. Una de las dos subfamilias plesiosorícidas está representada por la particular subfamilia euroasiática Butseliinae. Aquí describimos nuevos elementos dentales y postcraneales de Butselia biveri, la especie tipo del género Butselia, del inicio del Oligoceno en Bélgica. La especializada dentición anterior muestra un fuerte i2 caniniforme mientras los molares superiores e inferiores muestran una marcada evolución convergente con los carnívoros basales, especialmente los pequeños miácidos del Eoceno temprano. Los huesos tarsales de Butselia biveri también son identificados y descritos, sugiriendo una relación cercana con Nyctitheriidae pero indicando también algunas características convergentes con pequeños carnívoros escansoriales.

Palabras clave: Soricomorpha, Plesiosoricidae, Butselia, MP21, Bélgica. 


\section{INTRODUCTION}

Butselia biveri was originally described by Quinet \& Misonne (1965) based on two M1 and one M2 (interpreted as M3) from the Lower Oligocene (MP 21) of Hoogbutsel (Belgium). These authors considered B. biveri as a zalambdodont insectivore and assigned it to the new family Butselidae. In the same paper, they also described two lower molars that they referred to an unidentified genus and species of zalambdodont insectivore. Later, these lower molars were assigned to B. biveri by Butler (1972) who described and figured additional material of $B$. biveri from the Isle of Wight and moved the genus Butselia into the family Plesiosoricidae. Later, McKenna \& Bell (1997) considered the family Butselidae as a junior synonym of the family Plesiosoricidae in which they included the genera: Pakilestes Russell \& Gingerich, 1981 from the early Middle Eocene Kuldana Formation of Kohat, Pakistan; Ernosorex Wang \& Li, 1990 from the Middle Eocene of China; Butselia Quinet \& Misonne, 1965 (subject of this article); Pseudoneurogymnurus Gureev, 1979 from the Late Eocene-Early Oligocene of Eastern Kazakhstan; Plesiosorex Pomel, 1848 from the Late Oligocene to the Late Miocene of Europe, North America and Asia; and Meterix Hall, 1929 from the Middle Miocene of Nevada (although Meterix was regarded as a junior synonym of Plesiosorex by Green, 1977). However, Lopatin (2006) proposed to restore the group name Butseliinae as a subfamily of Plesiosoricidae and described the new genus Ordolestes from the Early Eocene of Mongolia that he considered as the earliest representative of the subfamily Butseliinae and the family Plesiosoricidae in general. He included Pakilestes and Butselia in this subfamily and recognized two subfamilies among Plesiosoricidae: Butseliinae Quinet \& Misonne, 1965 and Plesiosoricinae Winge, 1917.

Recently, Peigné et al. (2009) described Siamosorex debonisi from the latest Oligocene of Nong Ya Plong in Thailand. This species that belongs to the Plesiosoricidae and represents a unique example of convergent evolution with true carnivorans may have some relationships with the genus Butselia (Peigné et al. 2009). The same year, Ziegler (2009) described new dental specimens of Butselia biveri from the early Oligocene (MP 21 and MP 22) of Germany. In a phylogenetic analysis Ziegler (2009) showed the basal position of Butselia with respect to Plesiosorex, and the basal position of Plesiosorex soricinoides with respect to the numerous other Plesiosorex species.

In this study we describe new dental and postcranial elements of Butselia biveri from the lowermost Oligocene of Belgium, including for the first time the incisors and tarsal bones that allow reassessing the phylogenetic positioning of the Butseliinae. The specimens described were collected during a field work by one of the authors
(RS) in September 1999 at the locality of Boutersem, ca. $30 \mathrm{~km}$ east of Brussels, Belgium (Fig. 1). The site was

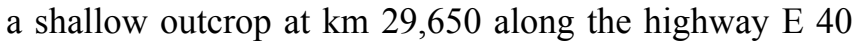
(A3), temporarily exposed during the High Speed Train (TGV) railway construction. The fossil bed occurred at the base of a fluvio-lacustrine complex, the Boutersem Member that overlies the latest Eocene marine Neerrepen Sands. The Boutersem Member that consists of shell-beds, clayey sands, and shelly sands belongs to the Borgloon Formation that is included in the Tongeren Group (Wouters \& Vandenberghe, 1994; Mayr \& Smith, 2001). The Boutersem sands contain molluscs (Marquet et al., 2008) and also yielded a rich fauna of vertebrates represented by amphibians (Folie et al., 2010), lizards (Augé \& Smith, 2009), birds (Mayr \& Smith, 2001), and mammals (Smith, 2003). The mammal fauna is correlated with the reference level MP 21 of the mammalian biochronological scale for the European Paleogene (Aguilar et al., 1997) defined on the fauna of Soumailles (Aquitaine, France). All the fossils are recorded from the oldest continental levels of the Early Oligocene near the «Grande Coupure» (Stehlin, 1909). The mammals are represented by several insectivorous taxa (see Smith, 2004 a, b, 2006 a, b, 2007; Smith \& van den Hoek Ostende, 2006) and among those, many teeth belonging to Butselia biveri that allow to reconstitute the dental upper and lower series. Next to the dental remains, several astragalus and calcaneum were easily attributed to Butselia biveri based on its size and abundance as only the well-known and abundant rodent Theridomys is larger than Butselia in Boutersem; all the other species are distinctly smaller than Butselia.

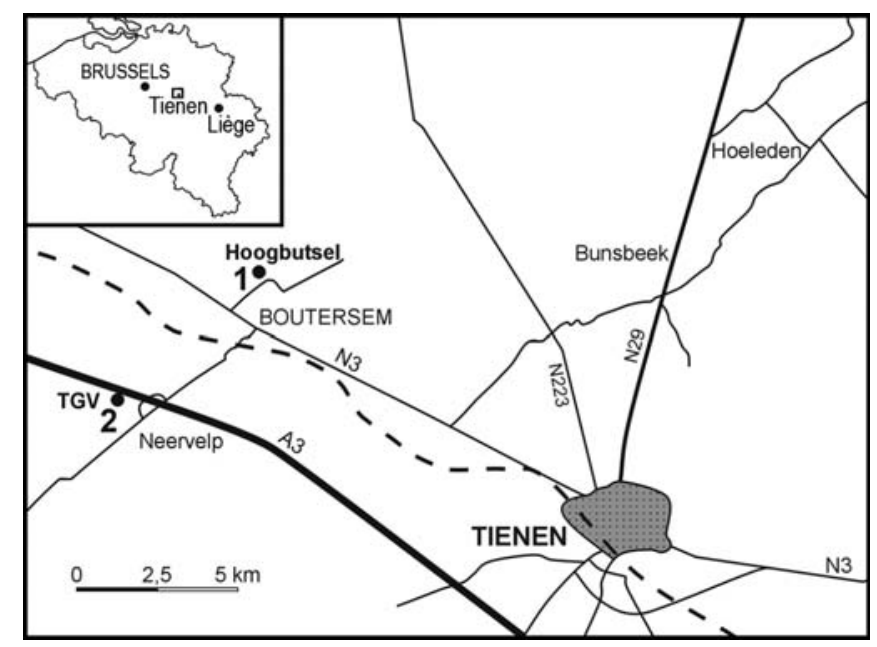

Figure 1. Location of the localities of Hoogbutsel (1) and Boutersem TGV (2). 


\section{MATERIALS AND METHODS}

The mammal systematic classification used here is that proposed by McKenna \& Bell (1997). The terminology used for dental crests and cusps is based on that defined by Van Valen (1966), completed for the subfamily Butselinae by Lopatin (2006). The terminology for the tarsal bones is that of Cifelli (1983). The fossils figured in this paper are housed at the Royal Belgian Institute of Natural Sciences (IRSNB). All of them were collected by one of the authors (RS) in the locality of Boutersem-TGV, except IRSNB M2057 which is from the type-locality of Hoogbutsel. The other specimens recorded from Boutersem-TGV are housed in the collection of R. Smith (RS).

\section{Abbreviations}

BSP: Bayerische Staatssammlung für Paläontologie und historische Geologie, München, Germany.

GSP-UM: Geological Survey of Pakistan, Islamabad, Pakistan.

IRSNB : Institut royal des Sciences naturelles de Belgique, Brussels, Belgium.

TGV : Train à Grande Vitesse (High Speed Train).

BOU: Boutersem-TGV.

\section{SYSTEMATIC PALAEONTOLOGY}

Grandorder LIPOTYPHLA Haeckel, 1866

Order SORICOMORPHA Gregory, 1910

Superfamily SORICOIDEA Fischer, 1817

Family Plesiosoricidae Winge, 1917

Subfamily Butseliinae Quinet \& Misonne, 1965

Genus Butselia Quinet \& Misonne, 1965

Type species Butselia biveri Quinet \& Misonne, 1965

Butselia biveri Quinet \& Misonne, 1965

Figs 2-5, Table 1

Holotype: IRSNB M1222 (see Quinet \& Misonne, 1965).

Type locality and horizon: Hoogbutsel near Boutersem, Flemish Brabant, Belgium (Glibert \& de Heinzelin de Braucourt, 1952; Smith, 2003), lowermost Oligocene, Boutersem Member, Borgloon Formation, Early Rupelian, reference level MP 21 (see Aguilar et al., 1997).

Other localities: Boutersem-TGV, Belgium (see Smith, 2003, 2004 a, b); Yarmouth, Isle of Wight, England, lower Hamstead Member (Butler, 1972; Hooker et al., 2004); Möhren quarry, Germany, MP21-22 (see Ziegler, 2009).
New material: Right dentary with $\mathrm{p} 4$ and trigonid of m1: IRSNB M2057; fragmentary left dentary with p4m1: BOU 365 RS; i1?: IRSNB M2058 (BOU 802 RS); i2: IRSNB M2059 (BOU 804 RS), BOU 805 RS, BOU 806 RS, BOU 807 RS, BOU 808 RS; i3: IRSNB M2118 (BOU 814 RS); p1: BOU 799 RS, IRSNB M2060 (BOU 813 RS); dp4: IRSNB M2061 (BOU 502 RS); p4: IRSNB M2062 (BOU 440 RS); m1: IRSNB M2063 (BOU 92 RS); m2: BOU 81 RS, BOU 194 RS, IRSNB M2064 (BOU 286 RS); m3: IRSNB M2065 (BOU 288 RS), BOU 513 RS, BOU 636 RS; fragmentary right maxilla with P3P4: IRSNB M2066a-b (BOU 594 RS); P3: BOU 575 RS; DP4: IRSNB M2067 (BOU 626 RS); P4: BOU 408 RS; M1: BOU 93 RS, BOU 95 RS, BOU 113 RS, BOU 231 RS, BOU 353 RS, IRSNB M2068 (BOU 567 RS), BOU 623 RS; M2: BOU 534 RS, IRSNB M2069 (BOU 552 RS), BOU 558 RS, BOU 574 RS, BOU 673 RS, BOU 677 RS, BOU 691 RS; M3: BOU 130 RS, BOU 255 RS, IRSNB M2070 (BOU 424 RS), BOU 621 RS, BOU 678 RS; Astragalus: IRSNB M2071 (BOU 800 RS), BOU 812 RS; Calcaneum: IRSNB M2072 (BOU 801 RS), BOU 809 RS, BOU 810 RS, BOU 811 RS.

Table 1: Measurements (in mm) of cheek teeth of Butselia biveri from Boutersem-TGV. L: length; 1: width; $\mathrm{n}$ : number of specimens; OR: observed range of variation; M: mean; $\sigma$ : standard deviation; V: coefficient of variation.

\begin{tabular}{|c|c|c|c|c|c|c|c|}
\hline & & $\mathbf{n}$ & \multicolumn{2}{|c|}{ OR } & $\mathbf{M}$ & $\sigma$ & $\mathbf{V}$ \\
\hline \multirow[t]{2}{*}{ DP4 } & $\mathrm{L}$ & 1 & \multicolumn{2}{|c|}{2.90} & - & - & - \\
\hline & 1 & 1 & \multicolumn{2}{|c|}{3.30} & - & - & - \\
\hline \multirow[t]{2}{*}{ P3 } & $\mathrm{L}$ & 2 & 2.30 & 2.45 & 2.38 & 0.11 & 4.63 \\
\hline & 1 & 2 & 1.60 & 1.80 & 1.70 & 0.14 & 8.24 \\
\hline \multirow[t]{2}{*}{ P4 } & $\mathrm{L}$ & 2 & \multicolumn{2}{|c|}{3.25} & - & - & - \\
\hline & 1 & 2 & 3.60 & 3.70 & 3.65 & 0.07 & 1.92 \\
\hline \multirow[t]{2}{*}{ M1 } & $\mathrm{L}$ & 7 & 2.35 & 3.60 & 2.51 & 0.08 & 3.19 \\
\hline & 1 & 7 & 3.60 & 4.00 & 3.84 & 0.14 & 3.65 \\
\hline \multirow[t]{2}{*}{ M2 } & $\mathrm{L}$ & 7 & 1.60 & 2.05 & 1.79 & 0.14 & 7.84 \\
\hline & 1 & 7 & 2.45 & 3.10 & 2.81 & 0.24 & 8.53 \\
\hline \multirow[t]{2}{*}{ M3 } & $\mathrm{L}$ & 5 & 1.00 & 1.15 & 1.07 & 0.07 & 6.54 \\
\hline & 1 & 5 & 1.35 & 1.60 & 1.52 & 0.12 & 7.89 \\
\hline \multirow[t]{2}{*}{$\mathrm{p} 1$} & $\mathrm{~L}$ & 1 & \multicolumn{2}{|c|}{1.15} & - & - & - \\
\hline & 1 & 1 & \multicolumn{2}{|c|}{0.85} & - & - & - \\
\hline \multirow[t]{2}{*}{$\mathrm{dp} 4$} & $\mathrm{~L}$ & 1 & \multicolumn{2}{|c|}{2.25} & - & - & - \\
\hline & 1 & 1 & \multicolumn{2}{|c|}{1.40} & - & - & - \\
\hline \multirow[t]{2}{*}{ p4 } & $\mathrm{L}$ & 2 & 2.10 & 2.25 & 2.18 & 0.11 & 5.06 \\
\hline & 1 & 2 & 1.40 & 1.60 & 1.50 & 0.14 & 9.33 \\
\hline \multirow[t]{2}{*}{$\mathrm{m} 1$} & $\mathrm{~L}$ & 2 & 2.90 & 3.10 & 3.00 & 0.14 & 4.67 \\
\hline & 1 & 2 & 2.30 & 2.30 & 2.30 & 0.00 & 0.00 \\
\hline \multirow[t]{2}{*}{$\mathrm{m} 2$} & $\mathrm{~L}$ & 3 & 2.15 & 2.30 & 2.22 & 0.08 & 3.61 \\
\hline & 1 & 3 & 1.80 & 2.00 & 1.90 & 0.10 & 5.26 \\
\hline \multirow[t]{2}{*}{$\mathrm{m} 3$} & $\mathrm{~L}$ & 3 & 1.45 & 1.55 & 1.48 & 0.06 & 4.04 \\
\hline & 1 & 3 & 1.20 & 1.25 & 1.23 & 0.03 & 2.43 \\
\hline
\end{tabular}




\subsection{Dentary}

The dentary is slender and elongated anteroposteriorly (Fig. 2). The symphysis is poorly marked but well extended from the tip of the jaw to below the anterior root of $\mathrm{p} 3$. The horizontal ramus is slender on the level of the symphysis. It becomes gradually somewhat labiolingually thicker from $\mathrm{p} 4$ to $\mathrm{m} 3$. The coronoid process is poorly preserved and seems to form a right angle with the horizontal ramus. The lower part of the dentary is relatively convex. There are two mental foramina, a small one below p2 and a larger one below the anterior root of p4 (on IRSNB M2057) or between the two roots of p4 (on BOU 365 RS). Doubling of the anterior foramen is observed in BOU 365 RS with a second foramen below the posterior root of $\mathrm{p} 3$. The posterior part of the dentary BOU $365 \mathrm{RS}$ is broken and does not show much information. The alveoli of the teeth are well preserved on both dentary fragments and attest the presence of at least two incisors, one single-rooted canine, single-rooted p1 and p2 (except on BOU 365 RS on which the alveolus of $\mathrm{p} 2$ is double-rooted) and two-rooted $\mathrm{p} 3$ to $\mathrm{m} 3$. The most anterior partially preserved alveolus is for a large curved incisor, probably i 2 and is followed by a very small curved and circular alveolus for i3. The alveolus of i1 is not preserved.

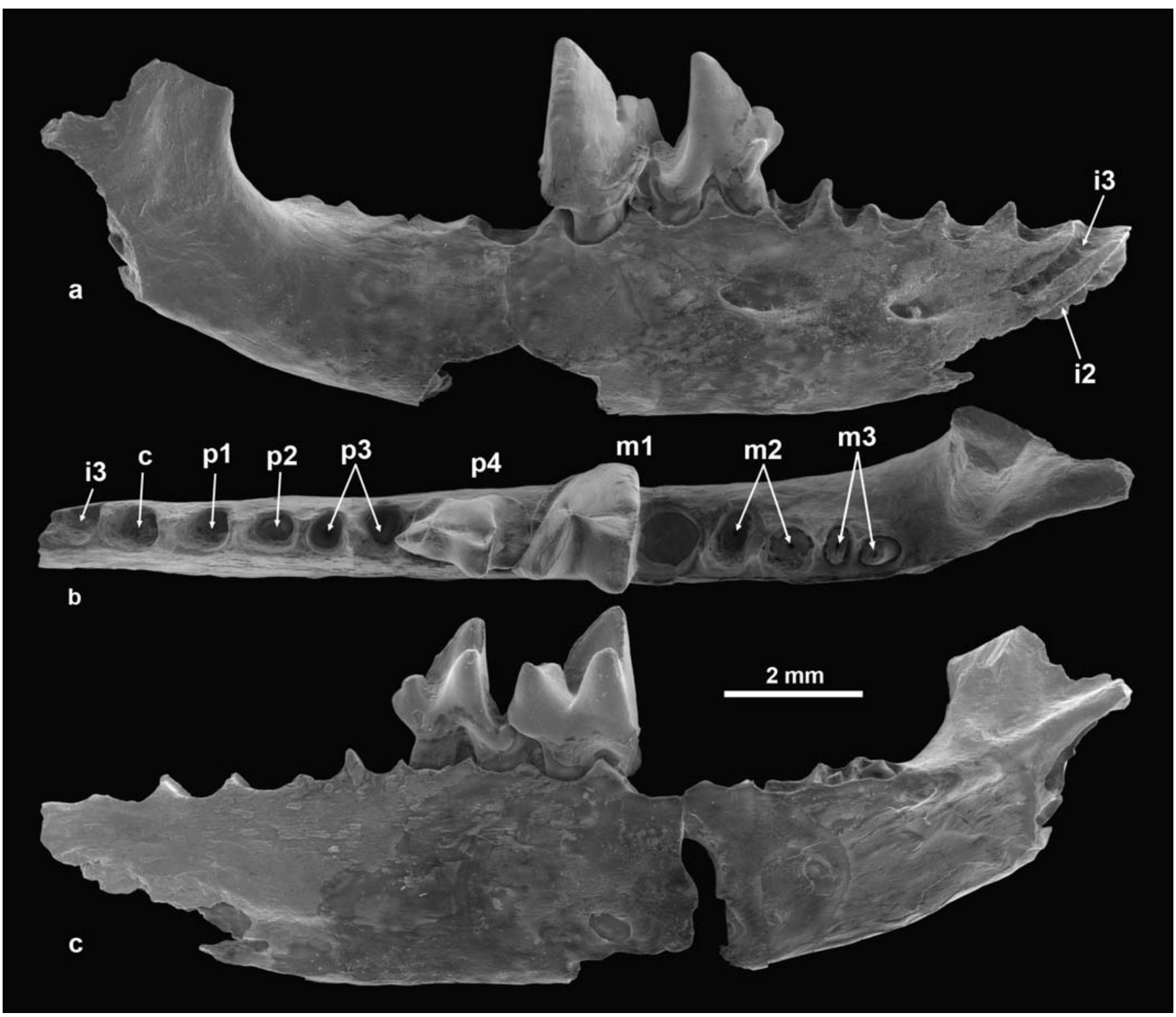

Figure 2. Right dentary IRSNB M2057 of Butselia biveri Quinet \& Misonne, 1965 with p4 and trigonid of m1 in (a) labial, (b) occlusal and (c) lingual views. 


\subsection{Lower dentition}

The tooth identified as a possible i1 (i1?) is a slightly curved long-rooted tooth that is compressed laterally (Figs $3 \mathrm{a}-\mathrm{c})$. The crown is slender with a posterior depression longitudinally divided in two by a thin central ridge. On the lateral side the crown shows a curved lateral ridge with a middle-sized accessory cusp at middle distance of the crown length. The medial ridge is curved, simple and joins posteriorly the lateral ridge. i2 is a large and long curved caniniform incisor with a slender and sharp-pointed crown (Figs 4d-f). The root is about twice the length of the crown and somewhat flattened on its medial side. The postero-lateral depression of the crown is longitudinally divided in two by a strong central ridge.
The $i 3$ is a very small and curved premolariform incisor (Figs 3g-h). The crown is very simple, low, and bears an accessory posterior cusp and a slight bulge on the anterior side.

The teeth increase in size from $\mathrm{p} 1$ to $\mathrm{p} 4$ and decrease from $\mathrm{m} 1$ to $\mathrm{m} 3$. $\mathrm{p} 1$ is procumbent and single-rooted (Figs $3 \mathrm{i}-\mathrm{k})$. The anterior crest of the main cusp is convex and sharp while the posterior crest also sharp is nearly straight and joined a tiny posterolingual accessory cusp. In occlusal view the two crests are aligned and the labial edge extends gradually anteroposteriorly. There is a weakly developed cingulid on the two edges of the tooth. The labial cingulid is longer and somewhat more developed than the lingual cingulid. Between these cingulids and the main cusp a small depression occurs on both sides, narrow on the lingual side and enlarged on the labial side.

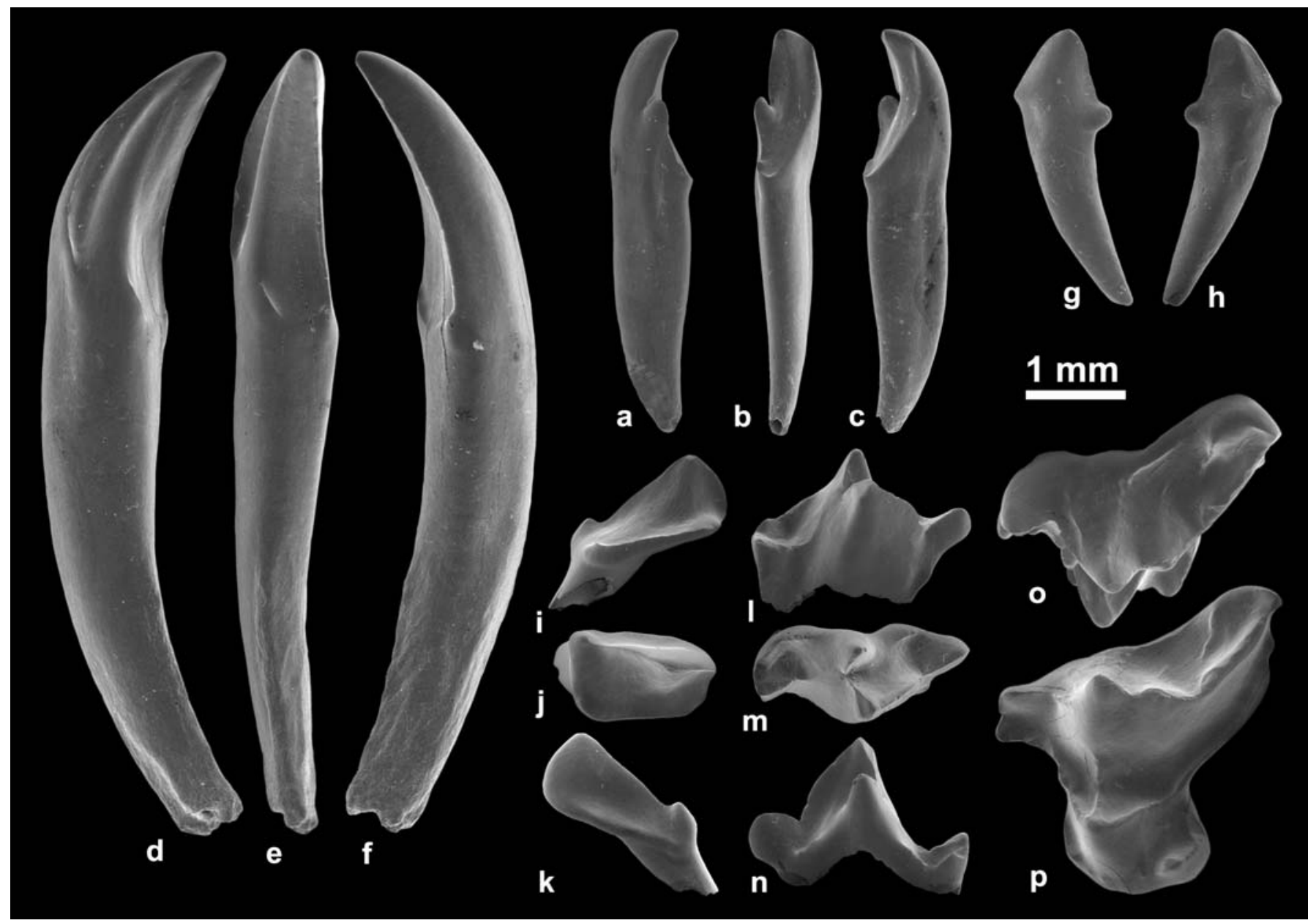

Figure 3. Anterior and decidual teeth of Butselia biveri Quinet \& Misonne, 1965. a-c) left i1? IRSNB M2058 (BOU 802 RS), (a) lateral, (b) posterior, (c) medial views; d-f) right i2 IRSNB M2059 (BOU 804 RS), (d) lateral, (e) posterior, (f) medial views; g-h) i3 IRSNB M2118 (BOU 814 RS), lateral and medial views; i-k) right p1 IRSNB M2060 (BOU 813 RS), (i) labial, (j) occlusal, (k) lingual views; l-n) right dp4 IRSNB M2061 (BOU 502 RS), (1) labial, (m) occlusal, (n) lingual views; o-p) left DP4 IRSNB M2067 (BOU 626 RS), (o) labial, (p) occlusal views. 


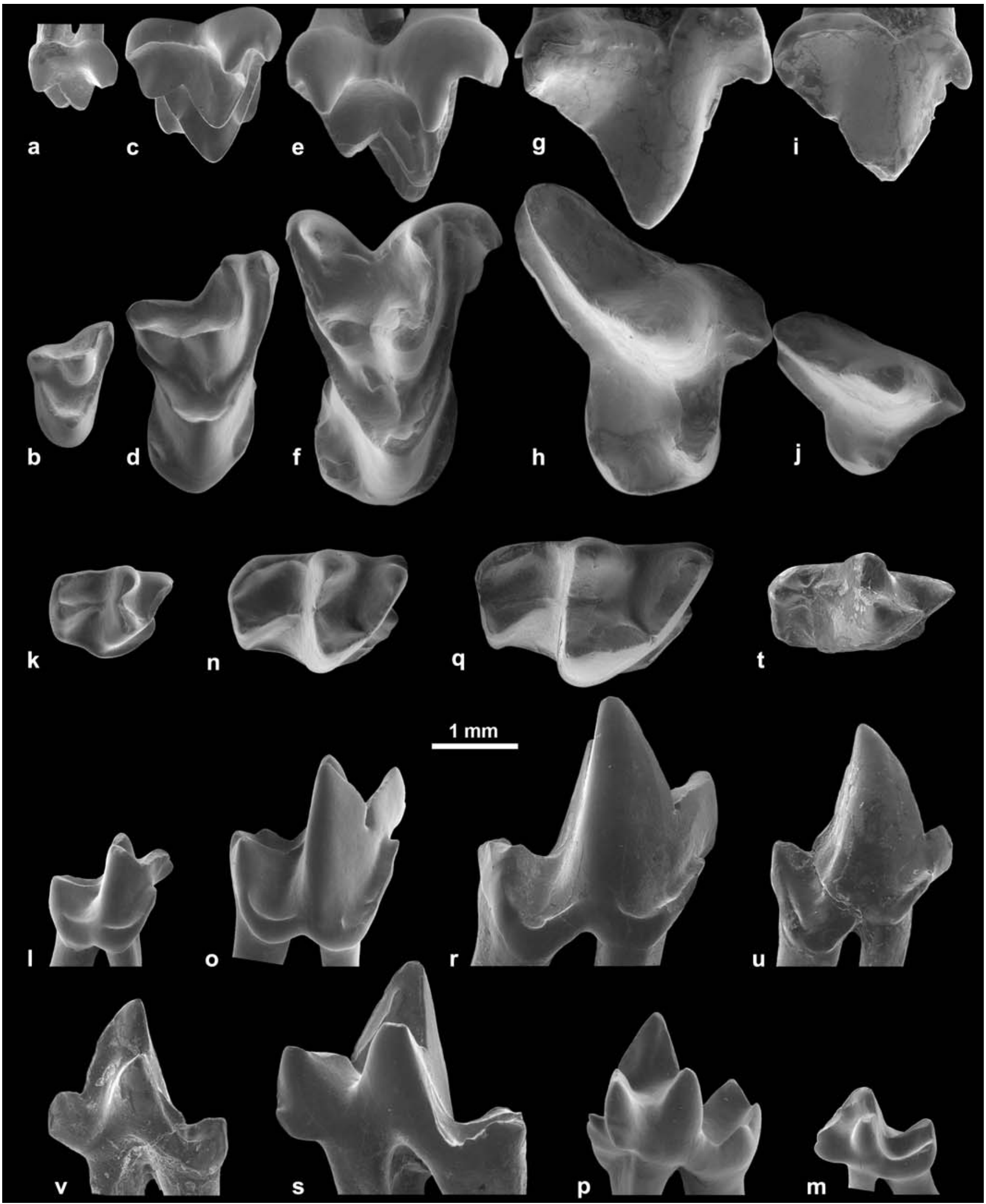

Figure 4. Upper and lower jugal teeth of Butselia biveri Quinet \& Misonne, 1965. a-b) left M3 (reversed) IRSNB M2070 (BOU 424 RS); c-d) left M2 (reversed) IRSNB M2069 (BOU 552 RS); e-f) right M1 IRSNB M2068 (BOU 567 RS); g-h) right P4 IRSNB M2066a (BOU 594 RS); i-j) right P3 IRSNB M2066b (BOU 594 RS) in labial and occlusal views; k-m) right m3 IRSNB M2065 (BOU 288 RS); n-p) left m2 (reversed) IRSNB M2064 (BOU 286 RS); q-s) right m1 IRSNB M2063 (BOU 92 RS); t-v) right p4 IRSNB M2062 (BOU 440 RS) in occlusal, labial and lingual views. 
The dp4 is similar in size to $\mathrm{p} 4$ (Figs 31-n). The trigonid is not high. The protoconid is sharp-pointed. The paraconid is procumbent and very well developed. The protolophid and the paralophid are sharp. The trigonid basin is largely opened lingually. A precingulid is present but its size and aspect are difficult to estimate because the tooth is damaged at this level. The talonid is incurved labially. A small entoconid and hypoconid are separated by a notch. The talonid basin is relatively deep. The entocristid and the cristid obliqua are sub-parallel in occlusal view.

The p4 has a tall trigonid with a particularly high protoconid (Figs 4t-v). The protolophid is long and sharp. The metaconid closely pressed against the protoconid, a little more posterior than it, is only different in its upper part and does not reach its height. The well-developed paraconid is anteriorly projected. A strongly developed precingulid occurs under the base of the protolophid and extends until the base of the protoconid. The extremely reduced prefossid is largely open lingually. The cristid obliqua reachs the middle height of the metaconid. The low and narrow talonid consists of a single crestiform cusp which is prolonged towards the cristid obliqua. This cusp is separated from the cristid obliqua by a weak notch. The reduced and shallow talonid basin is extremely narrow and lingually displaced. The hypoflexid is prolonged very low on the labial surface of the talonid which strongly goes down on the posterior root of the tooth. A thick cingulum borders all this posterior part.

The $\mathrm{m} 1$ is the largest tooth of the dentary (Figs 4q-s). Its trigonid, somewhat higher than that of $\mathrm{p} 4$, is much more massive. $\mathrm{m} 1$ is also longer and broader. The three trigonid cusps delimit a lingually open basin, definitely more important than that of $\mathrm{p} 4$. The paraconid, strongly developed, presents a thickening on the lingual side. The paracristid is strong, shearing, with a narrow deep carnassial notch. The precingulid, more prominent and longer that those of the premolars, nearly joined the postcingulum. The talonid is definitely shorter and narrower than the trigonid. In occlusal view, the lingual edge of the talonid and the cristid obliqua are sub parallel in $\mathrm{m} 1$ as in $\mathrm{m} 2$ and $\mathrm{m} 3$ also. The two $\mathrm{m} 1$ specimens present an important wear on the crests of the cusps.

The $\mathrm{m} 2$ is smaller than $\mathrm{m} 1$ (Figs $4 \mathrm{n}-\mathrm{p}$ ). Its trigonid is shorter than that of $\mathrm{m} 1$, the paraconid being smaller, less thick, and closer to the two other cusps. Trigonid and talonid are about equal in length. In labial view, the precingulid joined the postcingulid. The hypoconid is the main cusp of the talonid. The entoconid is less developed than the hypoconulid, these two cusps being close to each other. On the specimen BOU 194 RS which is not worn, they are not distinguishable from the postcristid-entocristid that forms only one long and curved crest. The trigonid and talonid basins are relatively deep.

The $\mathrm{m} 3$ is more reduced than $\mathrm{m} 2$ and extremely reduced in comparison with $\mathrm{m} 1$ (Figs $4 \mathrm{k}-\mathrm{m}$ ). Its paralophid is somewhat concave in occlusal view and the paraconid is anteriorly prominent. The pre- and postcingulids, are joined and well developed. The talonid has only two cusps, a hypoconid and a presumed hypoconulid.

\subsection{Upper dentition}

DP4 has a similar size and outline to P4 (Figs 3o-p). The labial edge is also rather similar to that of $\mathrm{P} 4$ although a little more sinuous in occlusal view. The paracone is the highest cusp of the tooth. The labial side is concave in lateral view. The paracrista is sharp. The well-developed crestiform parastyle is separated from the paracingulum by a notch open to the anterior side of the tooth. The postparaconule crest connects the top of the protocone. The preprotocrista joins a small paraconule on the anterior side of the tooth. The crestiform metacone is poorly individualized from the paracone. The metacrista is long and relatively sharp. The metastyle is very small. The metastylar lobe presents a thick stylar cusp extended postero-labially. The last is extended by a very fine small crest going up lingually and sub parallel to the metacrista. The two little cusps and the two sub parallel crests form a small basin open in the stylar area. The precingulum is well developed and shows a thin accessory cusp. The well-developed hypocone is well separated from the protocone.

P3 shows a triangular shape in occlusal view (Figs $4 \mathrm{i}-\mathrm{j}$ ). The paracone, the main cusp, is high. The metacone is very light and the centrocrista and metacrista are in the same line giving a blade-like aspect to the metastyle. The labial edge is sub-rectilinear or very slightly concave. The ectocingulum that borders the tooth is weaker in its centre. The parastyle is well developed and separated from the paracrista by a notch. The protocone, relatively low and small, is a little more powerful than the parastyle. There is no hypocone. The shallow protofossa, is continued by a gutter parallel to the metacrista and open at its posterolabial extremity.

P4 is definitely larger than P3 (Figs 4g-h). It is the highest tooth of the series. Both teeth are rather comparable in morphology. However, P4 has a more concave labial edge and is more transversally elongated. The metastylar lobe is strongly developed postero-labially. There is no interruption between the centrocrista and the metacrista which form only one long blade-like crest. The welldeveloped but antero-posteriorly short protocone is separated from a crestiform hypocone by a broad groove. Hypocone and parastyle are of similar size.

M1 is wide. The high paracone and the lesser-developed metacone are separated from the labial edge by a wide stylar shelf. The paracone is connected to a powerful stylocone by a very long paracrista. The stylocone, paracone and protocone are located on the same labiolingual axis. The stylocone, which is the highest stylar 
cusp, is separated from the parastyle by a rather broad and very long paracingulum that is connected to the protofossa. The parastylar lobe is much more developed than the metastylar lobe. The metastylar lobe presents a strong stylar cusp. The labial edge shows a very deep ectoflexus. The precingulum and the postcingulum, on which a small but well-developed hypocone is present, are nearly connected at the base of the protocone.

M2 is definitely smaller than M1 (Figs 4c-d). The anterior part of the tooth is rather similar to that of M1. The labial edge is dissymmetrical with the parastyle and stylocone present on a strongly developed and labially extended parastylar lobe. The stylar shelf, narrower in its posterior part is definitely less important than on M1. The precingulum and postcingulum, as well as the hypocone, are more discrete than on $\mathrm{M} 1$.

M3 is extremely reduced (Figs 4a-b). It resembles M2 in miniature and all the morphological characters are attenuated. However it does not show a metastylar lobe nor a precingulum. The postcingulum is vestigial and there is no hypocone.

\subsection{Tarsal bones}

\subsubsection{Calcaneum}

The proximal part of the tuber calcanei is medio-laterally compressed and very high dorso-plantarly (Figs 5a-e). There is a strong concavity high on the lateral side just proximal to the ectal facet. The ectal facet is relatively short proximo-distally and is situated a little nearer to the distal border than to the proximal border of the tuber. The long axis of the ectal facet makes an angle of about $40^{\circ}$ to the long axis of the tuber calcanei. A small fibular facet seems present but is not very distinct. The sustentacular facet is distally extended until the medio-distal border of the tuber. This distal extension of the sustentacular facet is small in surface. The proximal extremity of the sustentacular facet is situated at the level of the middle of the ectal facet. A nearly distal peroneal tubercule is somewhat laterally extended. The cuboid facet makes an angle of about $70^{\circ}$ to the long axis of the tuber in dorsal view and has a $L$ shape in distal view. The plantar tubercle is well developed.

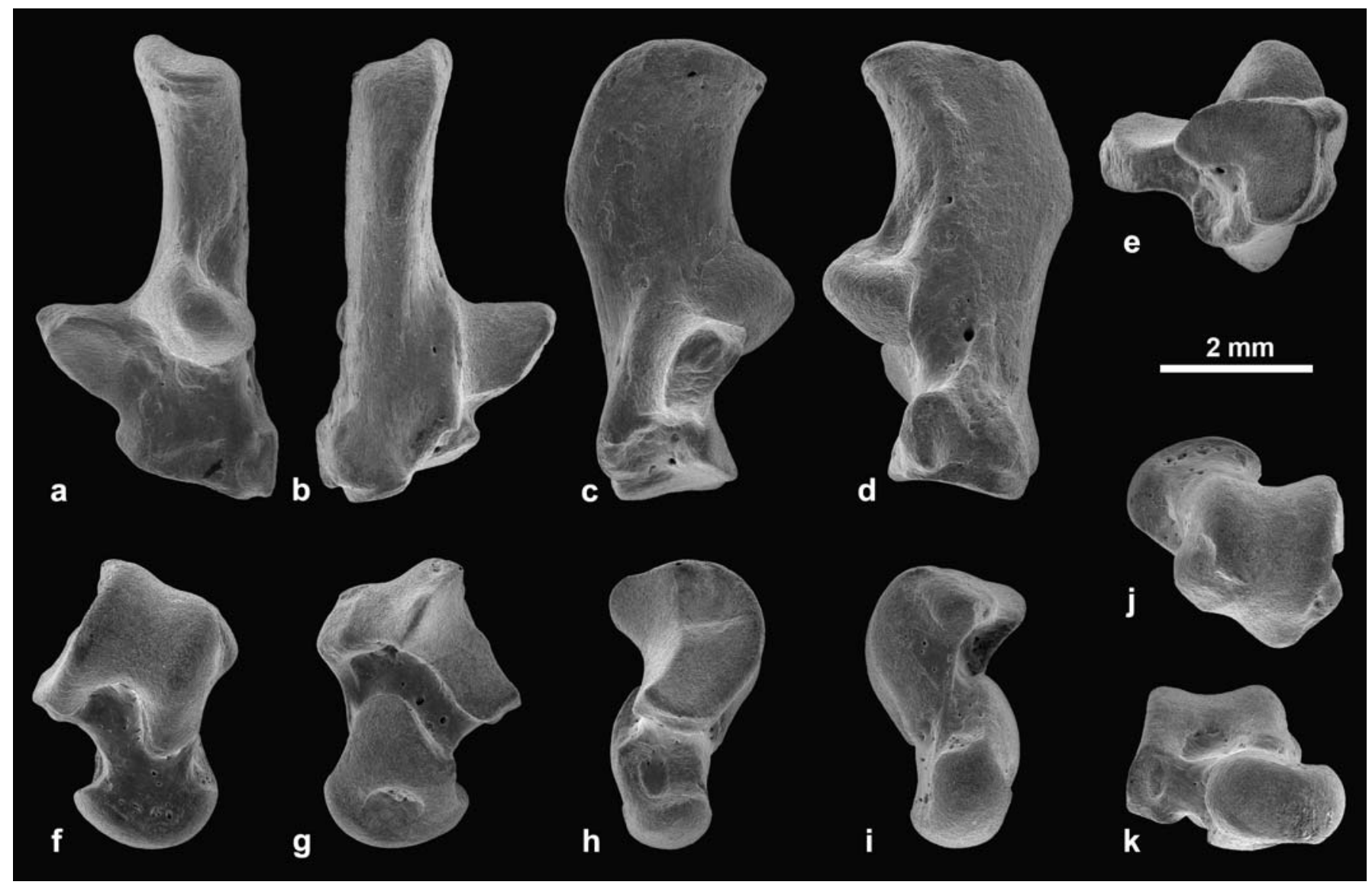

Figure 5. Tarsal bones of Butselia biveri Quinet \& Misonne, 1965. a-e) left calcaneum IRSNB M2072 (BOU 801 RS), (a) dorsal view, (b) plantar view, (c) medial view, (d) lateral view, (e) distal view; f-k) right astragalus IRSNB M2071 (BOU 800 RS), (f) dorsal view, (g) plantar view, (h) lateral view, (i) medial view, (j) proximal view, (k) distal view. 


\subsubsection{Astragalus}

The trochlea is grooved and of medium width (Figs $5 \mathrm{f}-\mathrm{k}$ ). It represents about $60 \%$ of the bone and makes an angle of $30^{\circ}$ with the long axis of the neck. The medial and lateral ridges are parallel and have about the same length giving a square shape to the trochlea in dorsal view with the distal border being especially grooved. Both ridges are high but the lateral ridge is sharper than the medial one. The ectal facet is long, narrow, concave, and extends medioplantarly. It is obliquely oriented with respect to the long axis of the neck. The neck is relatively strong and short. The fibular facet is vertical in dorsal view. The groove for the flexor fibularis tendon is narrow. There is no astragalar foramen. The sustentacular facet is wide, has a triangular shape and joins medially and laterally the navicular facet but leaves a shallow ovale depression between. The sustentacular facet is separated from the ectal facet by a broad groove. The navicular facet is medio-laterally long and dorso-plantarly narrow. It is nearly perpendicular to the main axis of the trochlea.

\section{DISCUSSION}

\subsection{Comparison of the dental morphology of Butselia with that of other Butseliinae}

The identification of all upper and lower jugal teeth of Butselia biveri at Boutersem-TGV reveals that the upper molar identified by Butler (1972) as M2 (p. 256, fig. 1 A-C) is actually a M1. In the same way, the upper molars BSP 1972 XI 223 identified as a M2 and BSP 1972 XI 243 as a M3 (Ziegler, 2009; fig. 2 M-N) are a M1 and a M2 respectively.

Pakilestes lathrius Russell \& Gingerich, 1981 is known from a $\mathrm{m} 1$, the trigonid of a $\mathrm{m} 2$, and a questionably $\mathrm{p} 4$. The $\mathrm{m} 1$ GSP-UM 122 is relatively similar in morphology to the $\mathrm{m} 1$ of Butselia but it is very smaller and thinner than that of Butselia. In occlusal view the posterior part of the talonid of $P$. lathrius is rounded whereas that of $B$. biveri is straighter. The protoconid, paraconid and metaconid are proportionally less massive on $P$. lathrius than those of $B$. biveri. On the other hand, the morphology of the $\mathrm{p} 4$ of $P$. lathrius is much more different from that of $B$. biveri. The $\mathrm{p} 4$ of $B$. biveri is elongated in occlusal view and not short and wide as in P. lathrius. The paraconid is reduced, very low and lingually oriented on P. lathrius whereas it is well developed and anteriorly oriented in $B$. biveri. The massive protoconid markedly convex in occlusal view on $P$. lathrius is much less developed and straighter on $B$. biveri. The metaconid is larger on $B$. biveri and not so posterolingually situated from the protoconid as on P. lathrius. The talonid of $B$. biveri is narrower and not distinctly basined as on
P. lathrius. The hypoflexid that is very deep in B. biveri is very weak in P. lathrius.

Ordolestes ordinatus Lopatin, 2006 does not show many differences with Butselia biveri. The most remarkable difference is for $\mathrm{m} 3$. The tooth is more elongated in $O$. ordinates and shows a hypoconulid that is missing in $B$. biveri.

Siamosorex debonisi Peigné et al., 2009 differs from $B$. biveri by its larger size and in having proportionally lower trigonids on the premolars and the molars. The labial cingulid of m1-3 is complete on $S$. debonisi while it is incomplete at the base of the protoconid on B. biveri. The m1-3 show a broader talonid basin and a paraconid more anteriorly directed on $B$. biveri. The cristid obliqua is more labialy directed on $S$. debonisi. The discovery of dentary fragments and isolated incisors of the butseliine Butselia biveri would indicate that the caniniform tooth of $S$. debonisi would not be a canine but an i2. The i1? of $S$. debonisi is similar to that of $B$. biveri with the accessory lateral cusp being a little more distal.

\subsection{Comparison of the tarsal bones of Butselia with those of other mammals}

The tarsal bones of Butselia present several plesiomorphic characters. Those characters are a trochlea not reduced in size and oblique to the neck, and a navicular facet that is oblique to the trochlea on the astragalus; an ectal facet and a cuboid facet that are oblique to the long axis of the tuber calcanei, and the retention of a peroneal tubercle on the calcaneum. However, the bones are also characterized by several apomorphies. Those are a symmetrical trochlea, a particular sustentacular facet on the astragalus, and a sustentacular facet that is distally extended on the calcaneum.

The astragalus of Butselia differs from that of amphilemurid erinaceomorphs, rodents and lagomorphs by the symmetrical trochlea with a perpendicular head. The navicular facet of the astragalus is not as elongated and wide proximo-laterally as in the erinaeomorphan Macrocranion (Godinot et al., 1996) and Zinocyon (Dunn \& Rasmussen, 2009). It is also distinguishable from primates by the short neck and from arctocyonids and most of the "condylarth" families by the absence of astragalar foramen and by a dorso-plantarly compressed navicular facet. Such a narrow navicular facet perpendicular to the trochlea axis is also present in the louisinid "condylarth" Paschatherium (Godinot et al., 1996) and the miacid Vulpavus (Heinrich \& Houde, 2006). But Butselia has no cotylar fossa and the trochlea is less grooved and asymmetrical than in louisinid condylarths (Godinot et al., 1996; Tabuce et al., 2006) and it differs from Vulpavus by the more grooved trochlea and particular shape of the sustentacular facet. Nevertheless, the comparison of the astragalus of Butselia 
with miacid carnivorans is interesting by the similarities in the proportions, and the medial and lateral ridges that are both high (see Spaulding et al., 2010 for figuration). The trochlea is much smaller than in the living soricomorphan Sorex (Hooker, 2001). The astragalus of Butselia resembles much that of the nyctitheriid Cryptotopos? sp. (Hooker, 2001) by the proportions, the grooved trochlea, the medial and lateral ridges equivalent in length, the absence of an astragalar foramen, the head perpendicular to the trochlea with a dorso-plantarly compressed navicular facet, and the particular shape of the sustentacular facet. However, it differs from Cryptotopos? sp. by the shorter neck and the higher medial ridge. These characters suggest an arboreal capability but probably with less mobility than in nyctitheriids.

The calcaneum of Butselia also resembles that of the nyctitheriid Cryptotopos? sp. (Hooker, 2001) by the proportions, the concavity proximo-lateral to the ectal facet, the inclined cuboid facet, and the distally extended sustentacular facet. However, it is different from Cryptotopos? sp. by the peroneal tubercle that is more distal and the ectal facet that is a little more oblique to the axis of the tuber calcanei. The latter is higher dorsoplantarly than in Cryptotopos? sp. and in this view resembles more to Tupaia. However, the distal peroneal tubercle of Butselia is a primitive feature different from Tupaia, nyctitheriids, plesiadapiforms, primates and early miacid carnivorans. Nevertheless, the general proportions of the calcaneum are relatively similar to those of early miacids (see Spaulding et al., 2010 for figuration).

\section{CONCLUSIONS}

The numerous new specimens of Butselia from BoutersemTGV allow to identify all the upper and lower jugal teeth and to complete the dental series of Butselia biveri. Butselia was probably an insectivore with carnivorous tendencies as previously suggested for the Asian butseliine Siamosorex (Peigné et al., 2009). The carnassial-like P4 and $\mathrm{m} 1$ associate with a reducing in size of the posterior molars are features known in some modern erinaceid and soricid insectivores (Butler, 1972, 1988) but in a less developed condition. Moreover, in the case of Butselia, these features are associated with a strong caniniform incisor that is also in favour of this hypothesis. The discovery and the study of the calcaneum and astragalus of $B$. biveri help in the phylogenetic positioning of the Butseliinae by suggesting a relationship with the no less enigmatic family Nyctitheriidae. Nevertheless, the general proportions of the tarsal bones resemble that of scansorial early miacids and thus confirm the convergent evolution of the Butseliinae with early true carnivorans of small size.

\section{ACKNOWLEDGEMENTS}

We would like to thank Pieter De Schutter for the donation of the figured specimen IRSNB M2057 to the IRSNB; Julien Cilis (IRSNB) for the SEM photographs. We are grateful to Ainara Badiola (Universidad del País Vasco, Bilbao) and Emmanuel Gheerbrant (MNHN, Paris) for improving the manuscript. This paper is a contribution to the research project $\mathrm{MO} / 36 / 020$ financially supported by the Belgian Federal Science Policy Office (to TS).

\section{REFERENCES}

Aguilar, J.P. et al. (106 authors) 1997. Synthèses et tableaux de corrélations / Syntheses and correlation tables. In: Actes du Congrès BiochroM'97 (eds. Aguilar, J-P., Legendre, S. \& Michaux, J.). Mémoires et Travaux de l'Institut de Montpellier, Ecole Pratique des Hautes Etudes, Sciences de la Vie et de la Terre, 21, 769-805.

Augé, M. \& Smith, R. 2009. An assemblage of early Oligocene lizards (Squamata) from the locality of Boutersem (Belgium), with comments on the EoceneOligocene transition. Zoological Journal of the Linnean Society, 155, 148-170.

Butler, P.M. 1972. The problem of insectivore classification. In: Studies of Vertebrate Evolution (eds. Joysey, K.A. \& Kemp, T.S.). Oliver and Boyd, Edinburgh, 253-265.

Butler, P.M. 1988. Phylogeny of the Insectivores. In: The Phylogeny and Classification of the Tetrapods, Volume 2: Mammals (ed. Benton, M.J.), Clarendon Press, Oxford, Systematics Association Special Volume, 35 B, 117141.

Cifelli, R.L. 1983. Eutherian Tarsals from the Late Paleocene of Brazil. American Museum Novitates, 2761, 1-31.

Dunn, R.H. \& Rasmussen, D.T. 2009. Skeletal morphology of a new genus of Eocene insectivore (Mammalia, Erinaceomorpha) from Utah. Journal of Mammalogy, 90, 321-331.

Fischer von Waldheim, G. 1817. Adversaria zoologica. Mémoires de la Société Impériale des Naturalistes de Moscou, 5, 368-428.

Folie, A., Smith, R. \& Smith, T. 2010. Amphibian diversity from the early Oligocene Borgloom Formation at Boutersem, Belgium. Journal of Vertebrate Paleontology, 30 (supplement to Number 3), 90A.

Glibert, M. \& de Heinzelin de Braucourt, J. 1952. Le gîte des vertébrés tongriens de Hoogbutsel. Bulletin de l'Institut royal des Sciences naturelles de Belgique, Sciences de la Terre, 28 (52), 1-22.

Godinot, M., Smith, T. \& Smith, R. 1996. Mode de vie et affinités de Paschatherium (Condylarthra, Hyopsodontidae) d'après ses os du tarse. Palaeovertebrata, 25, 225-242.

Green, M. 1977. A new species of Plesiosorex (Mammalia, Insectivora) from the Miocene of South Dakota. Neues Jahrbuch für Geologie und Paläontologie, 4, 89-198. 
Gregory, W.K. 1910. The Orders of Mammals. Bulletin of the American Museum of Natural History, 27, 1-524.

Gureev, A.A. 1979. Insectivores (Mammalia, Insectivora): Hedgehogs, Moles, and Shrews (Erinaceidae, Talpidae, Soricidae), vol. 4, no. 2. In: Fauna of the USSR: Mammals. Nauka, Leningrad [in Russian].

Haeckel, E. 1866. Systematische Einleitung in die allgemeine Entwicklungsgesgichte. In: Generelle Morphologie der Organismen (Georg Reimer, Berlin), 2, 17-160.

Hall, E.R. 1929. A second new genus of hedgehog from the Pliocene of Nevada. University of California Publications in Geological Sciences, 18, 230-231.

Heinrich, R.E. \& Houde, P. 2006. Postcranial anatomy of Viverravus (Mammalia, Carnivora) and implications for substrate use in basal carnivora. Journal of Vertebrate Paleontology, 26, 422-435.

Hooker, J.J. 2001. Tarsals of the extinct insectivoran family Nyctitheriidae (Mammalia): evidence for archontan relationships. Zoological Journal of the Linnean Society, 132, 501-529.

Hooker, J.J., Collinson, J.W. \& Sille, N.P. 2004. EoceneOligocene mammalian faunal turnover in the Hampshire Basin, UK: calibration to the global time scale and the major cooling event. Journal of the Geological Society, London, 161, 161-172.

Lopatin, A.V. 2006. Early Paleogene insectivore mammals of Asia and establishment of the major groups of insectivora. Paleontological Journal, 40 (Supplement 3), S205-S405.

Marquet, R., Lenaerts, J., Karnekamp, C. \& Smith, R. 2008. The molluscan fauna of the Borgloon Formation in Belgium (Rupelian, Early Oligocene). Palaeontos, 12.

Mayr, G. \& Smith, R. 2001. Ducks, rails and limicoline waders (Aves: Anseriformes, Gruiformes, Charadriiformes) from the lowermost Oligocene of Belgium. Geobios, 34, 547561.

McKenna, M.C. \& Bell, S.K. 1997. Classification of mammals above the species level. Columbia University Press, New York.

Peigné, S., Chaimanee, Y., Yamee, C., Marandat, B., Srisuk, P. \& Jaeger, J-J. 2009. An astonishing example of convergent evolution toward carnivory: Siamosorex debonisi $\mathrm{n}$. gen. n. sp. (Mammalia, Lipotyphla, Soricomorpha, Plesiosoricidae) from the latest Oligocene of Thailand. Geodiversitas, 31, 973-992.

Pomel, A. 1848. Etudes sur les Carnassiers Insectivores (extrait): Part 2. Classification des Insectivores. Archives des Sciences Physiques et Naturelles, 9, 244-257.

Quinet, G.E. \& Misonne, X. 1965. Les Insectivores zalambdodontes de l'Oligocène inférieur belge. Bulletin de l'Institut royal des Sciences naturelles de Belgique, Biologie, 41, 1-15.

Russell, D.E. \& Gingerich, P.D. 1981. Lipotyphla, Proteutheria (?), and Chiroptera (Mammalia) from the EarlyMiddle Eocene Kuldana Formation of Kohat (Pakistan). Contribution from the Museum of Paleontology, the University of Michigan, 25, 277-287.
Smith, R. 2003. Les vertébrés terrestres de l'Oligocène inférieur de Belgique (Formation de Borgloon, MP 21): inventaire et interprétation des données actuelles. Coloquios de Paleontología, volumen extraordinario, 1, 647-657.

Smith, R. 2004a. Nouveau nyctithère (Mammalia, Lipotyphla) de l'Oligocène inférieur de Belgique (Formation de Borgloon, MP 21). Bulletin de l'Institut royal des Sciences naturelles de Belgique, Sciences de la Terre, 74, 197204.

Smith, R. 2004b. Insectivores (Mammalia) from the earliest Oligocene (MP 21) of Belgium. Netherlands Journal of Geosciences / Geologie en Mijnbouw, 83, 187-192.

Smith, R. 2006a. Sigenyctia oligocaena n. gen. n. sp., nyctithère (Mammalia, Lipotyphla) de l'Oligocène inférieur de Belgique (Formation de Borgloon, MP21). Bulletin de l'Institut Royal des Sciences naturelles de Belgique, Sciences de la Terre, 76, 131-136.

Smith, R. 2006b. Le genre Euronyctia (Nyctitheriidae, Mammalia) en Europe occidentale. Strata, série 1, 13, 229-241.

Smith, R. 2007. Présence du genre Eotalpa (Mammalia, Talpidae) dans l'Oligocène inférieur de Belgique (Formation de Borgloon, MP 21). Bulletin de l'Institut royal des Sciences naturelles de Belgique, Sciences de la Terre, 77, 159-165.

Smith, R. \& van den Hoek Ostende, L.W. 2006. A new heterosoricid shrew from the lowermost Oligocene of Europe. Acta Palaeontologica Polonica, 51, 381-384.

Spaulding, M., Flynn, J.J. \& Stucky, R.K. 2010. A new basal carnivoramorphan (Mammalia) from the 'Bridger B' (Black's Fork Member, Bridger Formation, Bridgerian Nalma, middle Eocene) of Wyoming, USA. Palaeontology, 53, 815-832.

Stehlin, H.-G. 1909. Remarques sur les faunules de mammifères des couches éocènes et oligocènes du Bassin de Paris. Bulletin de la Société Géologique de France, 4è série, IX, 488-520.

Tabuce, R., Telles Antunes, M., Smith, R. \& Smith, T. 2006. Dental variability and tarsal morphology of the European Paleocene/Eocene mammal Microhyus. Acta Palaeontologica Polonica, 51, 37-52.

Van Valen, L.M. 1966. Deltatheridia, a new order of Mammals. Bulletin of the American Museum of Natural History, 132, 1-126.

Wang, B. \& Li, C. 1990. First Paleogene Mammalian Fauna from Northeast China. Vertebrata. Palasiatica, 28, 165205.

Winge, H. 1917. Udsigt over Insektaedernes indbyrdes Slaegtskab. Saertryk af Vidensk Meddel fra Dansk Naturhist Forening, 68, 83-203.

Wouters, L. \& Vandenberghe, N. 1994. Géologie de la Campine. Essai de synthèse. ONDRAF-NIROND, 94-12.

Ziegler, R. 2009. Plesiosoricids from early Oligocene fissure fillings in South Germany, with remarks on plesiosoricid phylogeny. Acta Palaeontologica Polonica, 54, 365371 . 
